ARQGA / 1068

\title{
FAMILIAL GASTRIC CANCER
}

\author{
Cláudio BRESCIANI, Rodrigo Oliva PEREZ and \\ Joaquim GAMA-RODRIGUES
}

ABSTRACT - Background - Familial aggregation of gastric cancer has pointed out to a possible hereditary and genetic factor involved in the carcinogenesis of this disease. The diffuse type gastric cancer patients are frequently younger and the tumor has locally infiltrative growth pattern early in its development. Observation of families with frequent early onset gastric cancer has led to the identification of a novel gene implicated in gastric cancer susceptibility: CDH1/E-cadherin. Diffuse familiar gastric cancer is defined as any family presenting: two first-degree relatives with diffuse gastric cancer, one of them with age under 50 years or at least 3 first-degree relatives irrespective age of onset. Case report - The family reported by us does not fit in any of the classification proposed. The precise identification of these families by clinical and molecular tools is of great importance. The case reported is an example of a family that probably is a form of hereditary gastric cancer not yet fully understood. Conclusion - Soon there will be new criteria, possibly including genetic and molecular characteristics.

HEADINGS - Stomach neoplasms, genetics. Genetic predisposition to diseases. Cadherins.

\section{INTRODUCTION}

The incidence of gastric cancer (GC) has shown a tendency to decrease during the past decade, particularly in western countries. Still, it represents one of the commonest cancers among us ${ }^{(9)}$.

Environmental factors such as diet and $H$. pylori infection have been implicated in the carcinogenesis of this disease. Recently, familial aggregation of GC has pointed out to a possible hereditary and genetic factor involved in this $\operatorname{process}^{(7,19)}$.

\section{Pathology}

Gastric cancer comprehends morphologically heterogeneous carcinomas. Multiple histopathological classifications have been proposed focusing mainly on tumor growth pattern and degree of differentiation among others.

LAURÉN's classification ${ }^{(12)}$ is one most utilized and roughly, defines two major groups of GC: diffuse and intestinal types. Therefore, one can distinguish between completely different carcinomas in respect to clinical, epidemiological and pathological features ${ }^{(4,12,13)}$. There are also disadvantages in using any of these classifications. Some GC do not fit in any of them, either because they share both group's features or because of characteristics not present in any of them.

The intestinal type according to Laurén's classification is the predominant GC in high-risk areas and is commonly associated with precursor lesions such as chronic gastritis and intestinal metaplasia. Typically it affects distal regions of the stomach and older patients. Hematogenic spread may lead to secondary lesions, most commonly hepatic metastasis ${ }^{(12,13)}$.

The diffuse type gastric cancer, on the other hand, is usually not associated with precursor lesions. Patients are frequently younger and the tumor has locally infiltrative growth pattern early in its development. Peritoneal and lymphatic metastases are often detected during operation ${ }^{(12,13)}$.

\section{Hereditary cancer}

Gastric cancer can sometimes be a manifestation of other syndromes that predispose to various cancers. The most important are hereditary non-polyposis colon cancer (HNPCC or Lynch I and II), Li-Fraumeni and familial adenomatous polyposis (FAP). Recently there has been evidence suggesting a syndrome associated specifically with $\mathrm{GC}^{(1,6,14,16,17)}$.

Initially, observations of families in New Zealand with frequent early onset $\mathrm{GC}$ has led to the identification of a novel

Study carried out at the Gastroenterology Department of the São Paulo University Medical School (FMUSP), São Paulo, SP, Brazil.

Address for correspondence: Dr. Cláudio Bresciani - Rua Jesuíno Arruda, 122 - ap. 141 - 04532-080 - São Paulo, SP, Brazil. e-mail: cbresciani@ig.com.br 
gene implicated in GC susceptibility. Germline genetic alterations in this candidate gene (CDH1-Ecadherin) could be responsible for a syndrome of familial gastric cancer $(\mathrm{FGC})^{(8)}$. Recent data indicates that $\mathrm{CDH} 1$ is associated with hereditary diffuse gastric cancer ${ }^{(10)}$.

\section{CDH1/E-cadherin}

The molecule coded by CDH1 is a transmembrane, $120 \mathrm{kD}$, glycoprotein. It is responsible for cellular-cellular adhesion by homophylic interactions between cellular basolateral surfaces. This interaction depends on its cytoplasmic domain and other catenins (gamma and beta) $)^{(3,15)}$

Expression is frequently "down-regulated" in a variety of experimental carcinoma models, particularly in advanced stages of the disease of signet-ring adenocarcinoma ${ }^{(2,3,5,15,18)}$.

Located in chromosome 16 (16q22.1), the gene is composed of 16 exons. Missense, truncating and splice mutations are common, the latter being associated specifically with gastric cancer. These mutations tend to be an early event in GC particularly in signet-ring adenocarcinomas $^{(2,3,5,15)}$.

The deletion of the chromosome area containing one of the alleles of CDH1 may unmask a previously silent mutation in the remaining allele. This mechanism called loss of heterozigosity is a frequent event involving tumor suppressor genes. Every cell has two alleles for the same gene. When one allele inherited is already mutated, any alteration involving the remaining allele ("wild type") would be sufficient to cause significant alteration in gene expression and cell damage. This "twohit" theory was first described by KNUDSON ${ }^{(1)}$ for retinoblastoma and forms the basis for the understanding of cancer susceptibility.

In 1999, criteria were established defining two groups of FGC based on pathological and epidemiological characteristics of the patients presenting with this disease ${ }^{(8)}$.

Diffuse FGC is defined as any family presenting: two first-degree relatives with diffuse $\mathrm{GC}$, one of them with age under $50 \mathrm{yr}$ or at least three first-degree relatives irrespective of age of onset. It is estimated that $25 \%$ of these cases are associated with $\mathrm{CDH} 1$ germline mutations ${ }^{(6,8)}$.

Intestinal FGC is defined according to the incidence of GC in the population of the area. Therefore, for high GC incidence areas the criteria are: at least three first-degree relatives, two consecutive generations affected and at least one being under $50 \mathrm{yr}$ old. These criteria are the same as the ones for HNPCC (Amsterdam criteria). For low GC incidence areas criteria would be only three first-degree relatives and at least one with age under $50^{(6,8)}$.

\section{CASE REPORT}

A 72-year-old oriental male (resident in Brazil for over 60 years), referred to our Service complaining of epigastric pain for 3 months.
He had no weight loss or history of gastrointestinal bleeding. Both parents had already died of cardiovascular disease before the age of 60. He had two brothers with advanced gastric cancer who died in 1999. Physical examination was unremarkable.

Endoscopy revealed an early gastric cancer, type IIc+III according to Japanese Society for Gastric Cancer Research (JSGCR), located on the lesser curvature of the stomach, $10 \mathrm{~cm}$ from the cardia. Biopsies confirmed adenocarcinoma and a total gastrectomy, D2 limphadenectomy with Roux-en-Y esophagojejunostomy was performed. The postoperative period was uneventful and he was discharged on the 8th day with normal oral intake.

Histopathological examination showed moderately differentiated adenocarcinoma, Borrmann III, infiltrating subserosa located on the lesser curvature of the antrum. All 48 lymph nodes examined were free of neoplastic involvement. There was moderate displasia and peri-neural, lymphatic and vascular tumor invasion were detected.

Patient's first brother was 73 years old when an advanced gastric cancer was diagnosed in another medical institution. A subtotal gastrectomy was performed for symptom palliation and the patient died of cardiovascular complications in immediate post-operative period. Pathological examination revealed a mucinous, mucocelular adenocarcinoma (diffuse type) of the antrum, infiltrating perigastric fat. There were also invasion of vascular, perineural and lymphatic tissue. All seven lymph nodes showed presence of neoplastic cells.

Patient's second brother was $78 \mathrm{yr}$ old and had died recently without any chance of surgical treatment. A Borrmann III lesion was diagnosed on stomach's body and biopsies revealed tubular-papillary adenocarcinoma. Since this patient was submitted to any kind of gastric resection we have no information about depth of penetration in the stomach wall or about lymphatic spread. Clinically the patient had signs of advanced disease such as carcinomatous ascites and cervical lymphadenopathy.

\section{DISCUSSION}

Recent advances in molecular biology and genetics had great impact on oncology, in particular, on cancers affecting the digestive system. Identification of hereditary forms of cancer and cancer susceptibility has been the focus of many research centers.

Hereditary non-polyposis colon cancer described by Lynch has become a model for hereditary cancer susceptibility. Several molecular events and genetic alterations are well understood in colon carcinogenesis of families affected by this syndrome. Inheritance of a single genetic mutation can predispose and lead to the development of cancer of the large bowel and others including gastric cancer, endometrial, urogenital and biliopancreatic. The Amsterdam criteria were created to facilitate the recognition of families affected by HNPCC. These criteria fail in some instances. Some families may 
not present all criteria and yet be affected. Further understanding of the molecular and genetic mechanisms involved may refine these criteria and in the near future identification of these families will be more accurate ${ }^{(1,17)}$.

Gastric cancer appears to be associated, in some cases, with a genetic and hereditary syndrome. Initially, all the progress obtained with HNPCC was transported to FGC. Criteria very similar to the Amsterdam's were created to help identify families affected and already separated two subgroups of this syndrome based on pathological and epidemiological characteristics. From the genetic and molecular point of view, the hereditary form of GC is poorly understood. Mechanisms involving CDH1 and E-cadherin may correspond to a minority of the cases and there must be many others involved ${ }^{(6,8)}$.

The family reported by our group shows three brothers with late onset gastric cancer of different histology with an aggressive behavior. Clearly this family does not fit in any of the classifications proposed. Taking into account the aggressive behavior of the cancer one could say that they are closer to the diffuse type group, since only one of them could be offered standard radical treatment. All descendents of their parents were affected and thus if we are assuming it is a hereditary form of GC we are probably dealing with a mutation of great penetrance. Furthermore, all of them were from Japan, a place where the environmental factor seems to be more important than genetic factors. Both of his parents died early with no signs of gastric cancer and this may be explained by the late onset in all of their children, in other words, they just did not live long enough.

The precise identification of these families by clinical and molecular tools is of great importance. This will have great impact on the understanding of the gastric cancer allowing creation of new diagnostic methods. It is very important to determine the exact role of CDH1 and
E-cadherin on FGC thus establishing adequate screening strategies and follow-up protocols to the affected and gene carrier families.

Treatment of gastric cancer in this setting will probably suffer some modifications. Total gastrectomy versus partial gastrectomy should be compared in patients with hereditary forms of gastric cancer, particularly of the diffuse type. These tumors are thought to be multicentric especially in these patients making the total resection a safer option. Great controversy will rise about prophylactic gastrectomy in high-risk patients. Recent data indicates that up to $75 \%$ of the patients with CDH1 germline mutations will develop diffuse gastric cancer ${ }^{(8)}$.

In 2001, a stunning report showed early gastric cancer in young, asymptomatic carriers of germ-line mutations of CDH1/E-cadherin submitted to prophylactic total gastrectomy. These patients had normal pre-operative endoscopic examination and after extensive pathological study of the resected specimen, macroscopic appearance were grossly normal but microscopic neoplastic cells or clusters of signet-ring cells were found in the lamina propria underlying normalappearing surface epithelium ${ }^{(10)}$.

The creation of criteria for FGC is important in order to alert and help physicians to recognize such families. These criteria should be useful in making early diagnosis and improving treatment results of gastric cancer in general. They should be viewed with great caution since they aggregate the more common forms of the disease. Some differences encountered in daily practice, such as the one encountered in the reported case, should exclude the possibility of a FGC syndrome. Soon, there will be new criteria, possibly including genetic and molecular characteristics, thus more accurate and probably more useful. The case reported is an example of a family that does not fit in any of the current classifications but probably is a form of hereditary gastric cancer not yet fully understood.

Bresciani C, Perez RO, Gama-Rodrigues J. Câncer gástrico familiar. Arq Gastroenterol 2003;40(2):114-117.

RESUMO - Racional - A agregação familiar do câncer gástrico é um dos indícios do envolvimento de fatores genéticos e da hereditariedade na gênese desta doença. Os pacientes com câncer gástrico difuso são freqüentemente mais jovens e o tumor apresenta característica infiltrativa local. A observação de familiar com alta incidência de câncer gástrico permitiu identificar o gene CDH1/E-caderina com envolvido na gênese da doença. O câncer gástrico familiar do tipo difuso é definido como a família que apresente dois parentes de primeiro grau com câncer gástrico difuso e um deles com menos de 50 anos de idade ou pelo menos três parentes de primeiro grau independentemente da idade. Descrição do caso - A família apresentada não se enquadra na classificação proposta, entretanto a precisa identificação destas famílias pode necessitar de outros parâmetros clínicos e moleculares. O caso aqui apresentado é um exemplo de família acometida por provável forma hereditária de câncer gástrico não totalmente compreendido. Conclusão - É provável que em breve haja modificações nos critérios possivelmente incluindo as características genéticas e moleculares em sua definição.

DESCRITORES - Neoplasias gástricas, genética. Predisposição genética para doença. Caderinas. 


\section{REFERENCES}

1. Aarnio M, Salovaara R, Aaltonen LA, Mecklin JP, Järvinen HJ. Features of gastric cancer in hereditary non-polyposis colorectal cancer syndrome. Int J Cancer 1997;74:551-5.

2. Berx G, Staes K, van Hengel J, Molemans F, Bussemakers MJ, van Bokhoven A, van Roy F. Cloning and characterization of the human invasion suppressor gene E-cadherin (CDH1). Genomics 1995;26:281-9.

3. Berx G, Becker KF, Höfler H, van Roy F. Mutations of the human E-cadherin (CDH1) gene. Hum Mutat 1998;12:226-37.

4. Borch K, Jönsson B, Tarpila E, Franzén T, Berglund J, Kullman E, Franzén L. Changing pattern of histological type, location, stage and outcome of surgical treatment of gastric carcinoma. Br J Surg 2000;87:618-26.

5. Bracke ME, van Roy FM, Mareel MM. The E-cadherin/catenin complex in invasion and metastasis. In: Günthert IU, Birchmeier W, editors. Attempts to understand metastasis formation I. Berlin: Springer Verlag; 1996. p.123-61. (Current Topics Microbiology and Immunology, v. 213).

6. Caldas C, Carneiro F, Lynch HT, Yokota J, Wiesner GL, Powell SM, Lewis FR, Huntsman DG, Pharoah PD, Jankowski JA, MacLeod P, Vogelsang H, Keller G, Park KG, Richards FM, Maher ER, Gayther SA, Oliveira C, Grehan N, Wight D, Seruca R, Roviello F, Ponder BA, Jackson CE. Familial gastric cancer: overview and guidelines for management. J Med Genet 1999;36:873-80.

7. Forman D, Newell DG, Fullerton F, Yarnell JW, Stacey AR, Wald N, Sitas F. Association between infection with Helicobacter pylori and risk of gastric cancer: evidence from a prospective investigation. Br Med J 1991;302:1302-5.

8. Guilford P, Hopkins J, Harraway J, McLeod M, McLeod N, Harawira P, Taite H, Scoular R, Miller A, Reeve AE. E-cadherin germline mutations in familial gastric cancer. Nature 1998;392:402-5.

9. Howson CP, Hiyama T, Wyinder EL. The decline in gastric cancer-epidemiology of an unplanned triumph. Epidemiol Rev 1986;8:1-27.
10. Huntsman DG, Carneiro F, Lewis FR, MacLeod PM, Hayashi A, Monaghan KG, Maung R, Seruca R, Jackson CE, Caldas C. Early gastric cancer in young, asymptomatic carriers of germ-line E-cadherin mutations. N Engl J Med 2001;344:1904-9.

11. Knudson AG. Mutation and cancer: statistical study of retinoblastoma. Proc Natl Acad Sci USA 1971;68:820-3.

12. Laurén P. The two histological main types of gastric carcinoma: diffuse and socalled intestinal type carcinoma. Acta Path Microbiol Scand 1965;64:31-49.

13. Laurén PA, Nevalainen TJ. Epidemiology on intestinal and diffuse types of gastric carcinomas. A time-trend study in Finland with comparison between studies from high- and low-risk areas. Cancer 1993;71:2926-33.

14. Lindor NM, Greene MH. The concise handbook of family cancer syndromes. Mayo familial cancer program. J Natl Cancer Inst 1998;90:1039-71.

15. Takeichi M. Cadherin cell adhesion receptors as a morphogenetic regulator. Science 1991;251:1451-5.

16. Varley JM, McGown G, Thorncroft M, Tricker KJ, Teare MD, Santibanez-Koref MF, Martin J, Birch JM, Evans DG. An extended Li-Fraumeni kindred with a gastric carcinoma and a codon 175 mutation of TP53. J Med Genet 1995;32:942-5.

17. Vasen HF, Wijnen JT, Menko FH, Kleibeuker JH, Taal BG, Griffioen G, Nagengast FM, Meijers-Heijboer EH, Bertario L, Varesco L, Bisgaard ML, Mohr J, Fodde $\mathrm{R}$, Khan PM. Cancer risk in families with hereditary non-polyposis colorectal cancer diagnosed by mutation analysis. Gastroenterology 1996;110:1020-7.

18. Vos CB, Cleton-Jansen AM, Berx G, de Leeuw WJ, ter Haar NT, van Roy F, Cornelisse CJ, Peterse JL, van de Vijver MJ. E-cadherin inactivation in lobular carcinoma in situ of the breast: an early event in tumorigenesis. Br J Cancer 1997;76:1131-3.

19. Zanghieri G, Di Gregorio C, Sacchetti C, Fante R, Sassatelli R, Cannizzo G, Carriero A, Ponz de Leon M. Familial occurrence of gastric cancer in the 2-year experience of a population-based registry. Cancer 1990;66:2047-51.

Recebido em 10/9/2002. Aprovado em 25/11/2002. 